\title{
Acceleration of starts up business in agriculture through improvement of production, financial and marketing system
}

\author{
Alfu Laila \\ University of Darussalam Gontor and University of Sultan Ageng Tirtayasa, alfulaila@untirta.ac.id \\ Lutfy Ditya Cahyanti \\ University of Darussalam Gontor
}

See next page for additional authors

Follow this and additional works at: https://scholarhub.ui.ac.id/ajce

Part of the Social and Behavioral Sciences Commons

\section{Recommended Citation}

Laila, Alfu; Cahyanti, Lutfy Ditya; Etica, Use; and Trisnaningrum, Niken (2019). Acceleration of starts up business in agriculture through improvement of production, financial and marketing system. ASEAN Journal of Community Engagement, 3(1).

Available at: https://doi.org/10.7454/ajce.v3i1.167

Creative Commons License

\section{(c) (i) ()}

This work is licensed under a Creative Commons Attribution-Share Alike 4.0 License.

This Research Article is brought to you for free and open access by the Universitas Indonesia at ASEAN Journal of Community Engagement. It has been accepted for inclusion in ASEAN Journal of Community Engagement. 


\title{
Acceleration of start-up business in agriculture through improvement of production, financial and marketing systems
}

\author{
Alfu Laila ${ }^{a b^{*}}$, Lutfy Ditya Cahyantia, Use Etica ${ }^{a}$, Niken Trisnaningruma \\ ${ }^{a}$ University of Darussalam Gontor, Indonesia \\ ${ }^{b}$ University of Sultan Ageng Tirtayasa, Banten, Indonesia
}

Received: March 5th 2019|| Revised: May 11th, 2019 || Accepted: June 19th 2019

\begin{abstract}
Due to increased unemployment among graduates, the University of Darussalam Gontor-Indonesia provided a program for strengthening entrepreneurship in start-up businesses in the agricultural sector. To achieve this objective, a community empowerment program was created that includes four strategic levels namely, 1) assessment; 2) training; 3) mentoring; and 4) monitoring and evaluation. This program was applied to 8 start-up businesses in sub sectors such as horticulture production, aquaculture, livestock, and agro-industrial. Assessment analysis resulted in three main targets on the entrepreneurship training program including 1) improvement of production; 2) development of a financial system, and 3) expansion of the marketing network. After 6 months, the community empowerment program improved acceptable and profitable production through different technology implementation methods. To build financial systems, every group recorded financial data through a Microsoft excel program template, and created a strategic plan based on present information and educated projections. Furthermore, every business unit had to be proficient in operating the website and with social media accounts for developing marketing network. General evaluation confirmed that this program could gradually enhance the skills of business owners/entrepreneurs. Good education in entrepreneurial skills in start-up businesses could drive sustainable performance and growth small-medium enterprises.
\end{abstract}

Keywords: entrepreneurship; start-ups; business; agriculture; economic

\section{Introduction}

The rising education levels among the population has resulted in an increasing number of university graduates (Nemcek, Kremenova, and Fabus, 2015). In Indonesia, the number of bachelor's graduates rapidly increased from 635,970 in 2013 (Ministry of Research, 2013) to 874,536 in 2018 (Ministry of Research, 2018). On the other hand, the number of young people in the labor market is gradually reducing compared to the number of fresh graduates. This fact is shocking because the percentage of unemployed graduates from the university level increased from 5.9\% in 2013 to $10.4 \%$ in 2018. From these statistics, the percentage of unemployed graduates increased by $4.6 \%$ in the last 5 years (Bureau, 2018). This means that the labor market is unable to absorb the growth of young graduates. Furthermore, graduates 
Alfu Laila, Lutfy Ditya Chayanti, Use Etica, Niken Trisnaningrum | ASEAN Journal of Community Engagement | Vol. 3, No. 1, 2019

find it harder to find job in line with their qualifications. The current situation is such that there is a clear imbalance between jobseeker qualifications and job vacancies (Rahmat et al., 2017). The increase of graduate unemployment rates has a negative impact not only at the personal level but also for the economy.

For the last ten years, entrepreneurship has had an important policy focus. The Ministry of Education has been issued a Presidential Instruction no 17 of 2010, on the management and organization of education. This instruction obliges institutions to develop graduates who are critical, creative, innovative, independent, confident, and have an entrepreneurial mindset as one of objectives of national education. To reach this purpose, most higher education institutions are required to ensure that all students are taught an entrepreneurship subject as a part of the curriculum. Even though an entrepreneurship course is taught in most of higher education in Indonesia (Ardianti, 2009; Noya and Setiyati, 2015; Utami, 2017), the course is ineffective at producing well-educated entrepreneurs who can create jobs (Ghina, 2014). Most college graduates tend to become job seekers in government or private companies. This outcome shows that there is quite a weak link between the course output and an entrepreneurial mindset. Most of entrepreneurship courses are lectured in classes. Students prefer doing real business than having classroom lectures (Ardianti, 2009). Through practicing business, for example as an extracurricular activity, the knowledge and skills needed would increase (Cui, Sun, and Bell, 2019). Furthermore, collaboration program between educational institutions and students can enhance students' interest in business (Bauman and Lucy, 2019; Hadi, Suardi, and Cahaya, 2015).

Nowadays, there are only few youngsters who are interested in building new businesses. They are engaged through information and communication technologies (ICTs) such as ecommerce, FinTech, game and others (Zaky et al., 2018). However, ICTs can also contribute sustainability in an agro-food system (Bilali and Allahyari, 2018). Furthermore, business development in agriculture is becoming core in some parts of Indonesia (Ridha and Wahyu, 2017). Entrepreneurship in the agricultural sector has become necessary to support the need of food among the Indonesian population. Currently, agriculture is growing intensively 
modern to increase yields for food security. Industrialization also tends to emerge in some agricultural sectors (0. et al., 2017).

Start-up businesses have the potential to decrease unemployment among graduates through innovation and job creation (Lukes, Longo, and Zouhar, 2019). In addition, micro and small enterprises contribute to the development of an economic nation (Obi et al., 2018). Start-up business requires entrepreneurial skills to create and develop business activities such as production, marketing, and economically regulated context. However, many startups in agriculture are inadequate on internal resources including entrepreneurial skill (Khayri, Yaghoubi, and Yazdanpanah, 2011). Entrepreneurship in agriculture requires focus on entrepreneurial skills (Seuneke, Lans, and Wiskerke, 2013) .

An entrepreneur development program is necessary to stimulate economic growth. In some of the developing countries entrepreneurship development programs have been published to stimulate entrepreneurial interest and to develop entrepreneurs (Adjimah and Akli L. P., 2014). The programs are designed for students, unemployed graduates (Onuekwusi, et al. 2014), and/or women (Masur, Jadhav, and Sarojani, 2014). Some of the programs emphasized that the participants were rising gradually to build business units. In other programs, the activities increased participants' knowledge (Priyanto, 2012), development and management capacity (Kurniati, 2015).

To develop students who can create start-up businesses, the University of Darussalam Gontor has realized community engagement through entrepreneurship development programs. The program aims to guide their students to develop owner's skill based on each business unit's trait. Within joining this program, they could get well-educated in entrepreneurial skills for further business development. Hence, they will contribute to the national economic growth through jobs creation and innovation.

\section{Methods}

\subsection{Participants}

In this community empowerment project, there were 8 participants' start-up businesses in the agriculture sector, operating in various sub-sectors including horticulture production, aquaculture, livestock, and agro-industrial. Horticulture production consists of Fresh Veta, 
Alfu Laila, Lutfy Ditya Chayanti, Use Etica, Niken Trisnaningrum | ASEAN Journal of Community Engagement | Vol. 3, No. 1, 2019

Al-Gitza, and Chili. Aquaculture is Bioflock, whereas livestock is Joper. Nugget, Fruida, and Glorins; were all grouped as agro-industrial products.

\subsection{Procedure}

To achieve the objectives, a community empowerment program consisting of four strategic levels, was created. The four levels include: 1) assessment; 2) training activities; 3) mentoring; and 4) monitoring and evaluation.

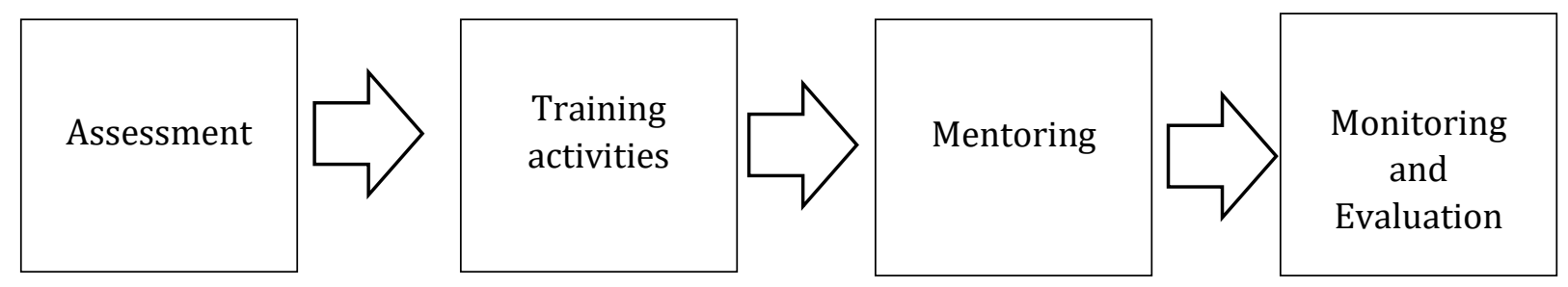

Fg. 1 Community empowerment process

\section{1) Assessment}

Assessment aimed to identify and analyze start-up business groups. Each group was identified through an in-depth interview in order to understand the level of entrepreneurial knowledge, motivation, constraint, opportunities, etc.

\section{a) Identification}

The interviews took place at the University of Darussalam Gontor in April 2018. The main respondents were individuals leading the development of businesses. The questionnaires consisted of 10 questions, each with several deep sub questions. The questions were strongly related to three major interview themes. The first theme aimed to explore daily activities related to work. Exploring daily activities was a necessary starting point to the introduction of the businesses. The second themes focused on knowledge, skill, experience, and network for each business. The third question discussed the background, motivation, satisfaction, support, and challenge. The interview took approximately an hour for each group. 

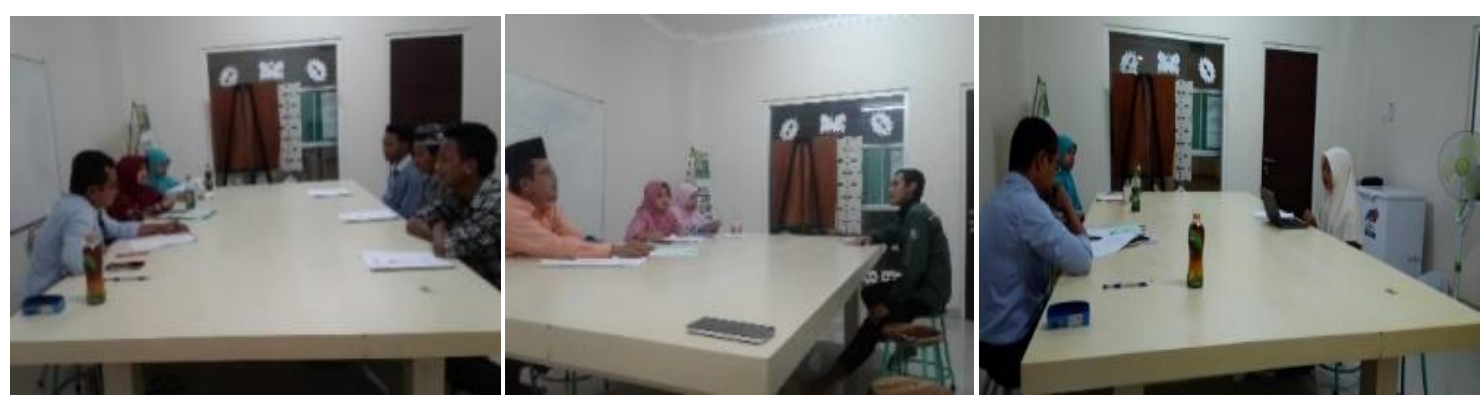

Fg. 2 Interviews to start-up business groups

Source: Authors (2018)

\section{b) Analysis}

The analysis stage aimed at the conceptualization of entrepreneurial learning design and was express for the design of further activities. As a first step, the results of the interviews were read repeatedly to understand the meaning of responses. Later, the main aspect of entrepreneurial learning experience for each business unit had been studied intensively and labeled specifically. These labels were divided into sub themes. The most frequently piece of sub theme for each business unit had its traits (Figure 3). Finally, it resulted in three main aspects of designing our entrepreneurship training that included production, business feasibility, and marketing. The three main themes were used as the basis for the following training activities section.

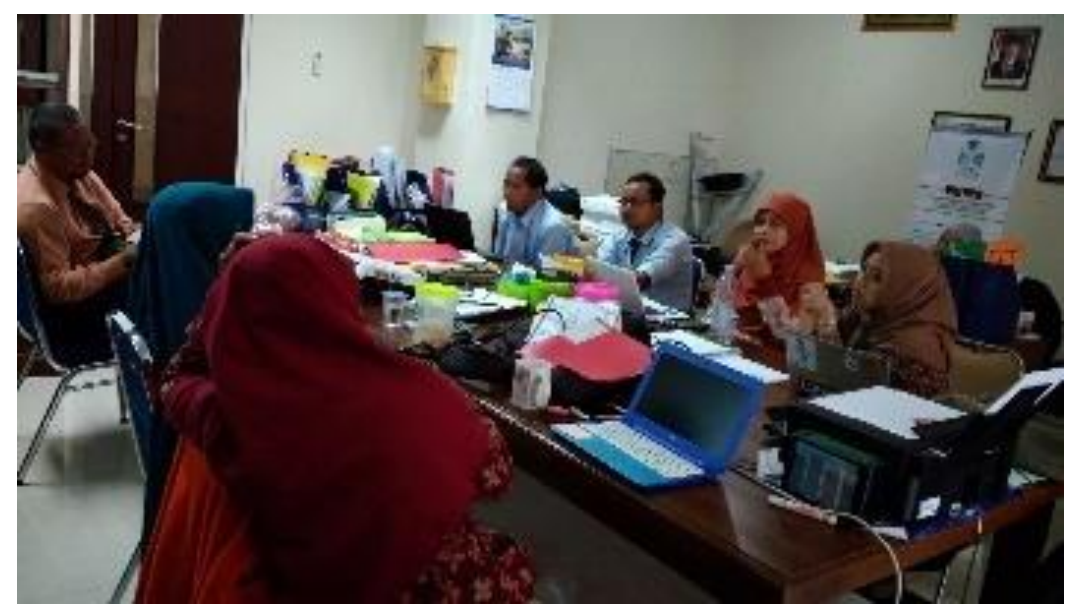

Fg. 3 Entrepreneurial learning analysis

Source: Authors (2018) 


\section{2) Training activities}

In this section, this program focused on three main themes which were production, business feasibility, and marketing network as the main targets which would be driving entrepreneurial learning. Program design turned into the main training activity. Since every business group had its unique traits, the programs were created for different business groups based on the group target. In this process, program and activities schedule were designed for 6 months since May to October 2018 took place in classroom, and in the field.

\section{3) Mentoring}

Mentoring aimed at guiding all the business group units during this program. In this process, 8 start-up business groups were divided into 4 sub-groups. Each two subgroups were guided by a facilitator. Every facilitator had to spend time to guide the groups during the programs both in the classroom and in the field. The guides visited the production area every week for advance monitoring problems and opportunities in business.
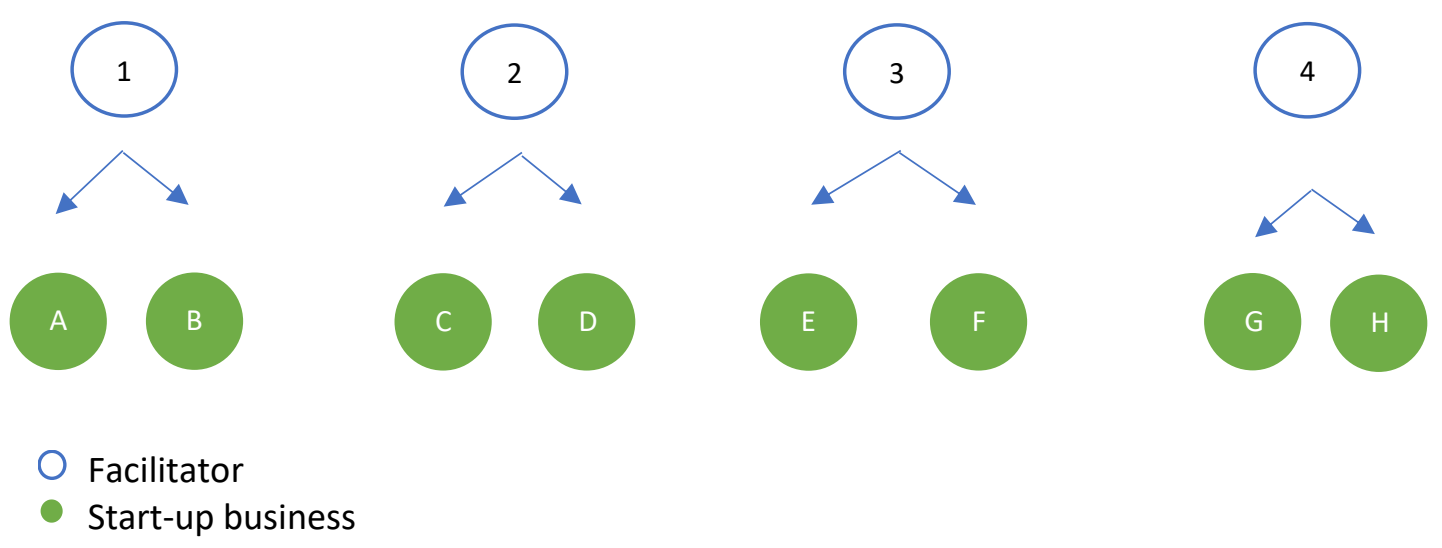

Fg. 4 Mentoring model

\section{4) Monitoring and Evaluation}

Monitoring and evaluation were aimed at maintaining the programs going on the right course. Internal monitoring and evaluation were conducted every two weeks. In 
Alfu Laila, Lutfy Ditya Chayanti, Use Etica, Niken Trisnaningrum | ASEAN Journal of Community Engagement | Vol. 3, No. 1, 2019

this program, all the facilitators discussed solving the problems to every business group. Monitoring and evaluation for all the start-up business groups was held twice a year in July and October through group discussions, direct dialogue and filling in questionnaires. First, all of participants were invited to join the group discussion. Every participant could share their challenges and developments when joining the program while others were permitted to respond to feedback (Figure 5a). In the second step, they were invited for direct dialogue. In this step, the discussions focused on application of the training to the development of daily business activities. In the last session, all members were requested to fill in the questionnaires containing 10 questions related to their feedback on this program (Figure 5b).

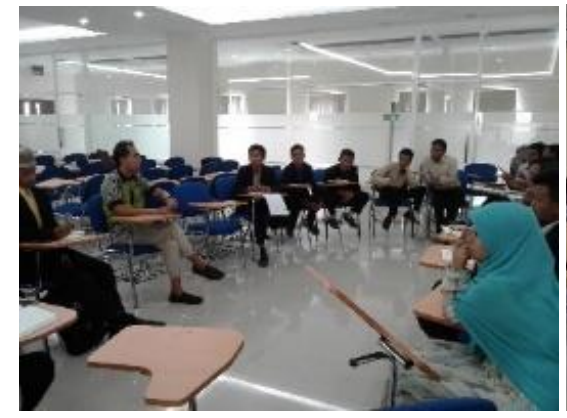

(a)

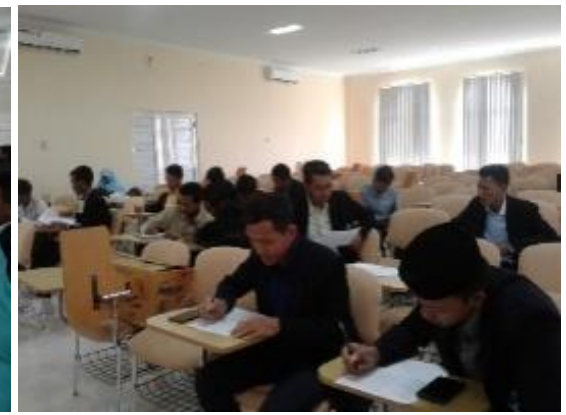

(b)

Fg. 5 Monitoring and evaluation through (a) Group discussion forum and direct dialogue; and (b) Questionnaire filling Source: Authors (2018)

\section{Result and Discussion}

\subsection{Assessment}

Table 1 presents a summary of the start-up business participants' profile. Business units were classified into 4 sub-groups based on the participants' duration of experience. The first group consisted of Fresh Veta, Al Gitza, Joper, and Nugget, which had the shortest experience in agribusiness. Chili and Fruida had longer experience in entrepreneurship while the longest experiences included Bioflock and Glorins units. 
Table 1. Agriculture Business Start-up Units (2018)

\begin{tabular}{|c|c|c|}
\hline Experience & Business Unit & Description \\
\hline \multirow[t]{5}{*}{$1-3$ months } & Fresh Veta & Vegetable production \\
\hline & Al-Gitza & Mushroom production \\
\hline & Joper & 'Kampong' (Jowo Super) chicken \\
\hline & & production \\
\hline & Nugget & Catfish nugget production \\
\hline \multirow[t]{2}{*}{ 4-6 months } & Chili & Chili production \\
\hline & Fruida & Fresh fruit juice production \\
\hline \multirow[t]{2}{*}{ 6-12 months } & Bio floc & Catfish production using bio floc system \\
\hline & Glorins & Palm sugar snacks production \\
\hline
\end{tabular}

Fresh Veta is a start-up agribusiness unit for the purpose of vegetable production. The founders possess various formal education backgrounds in fields such as agro-technology and economics. The business unit is in Ponorogo, East Java. The major products from this farm are water spinach and tomato. The mission of this business is to produce healthy vegetables with less pesticide. In the future, it intends to produce organic vegetables. Throughout the early season, owners engaged in the cultivation of multiple crops. The owners would harvest water spinach every month while tomatoes were harvested every three months. These products were offered to consumers directly without the involvement of third parties such as retailers, wholesalers or other middlemen. The production performance varied due to climate fluctuations such as the emergence of drought in supposedly rainy season. Moreover, these climatic fluctuations caused increasing cost of production due to irrigation water use. The owners, who were just starting up in horticultural production had less entrepreneurial skills to manage cultivation costs along the way to make the business profitable. 
Alfu Laila, Lutfy Ditya Chayanti, Use Etica, Niken Trisnaningrum | ASEAN Journal of Community Engagement | Vol. 3, No. 1,

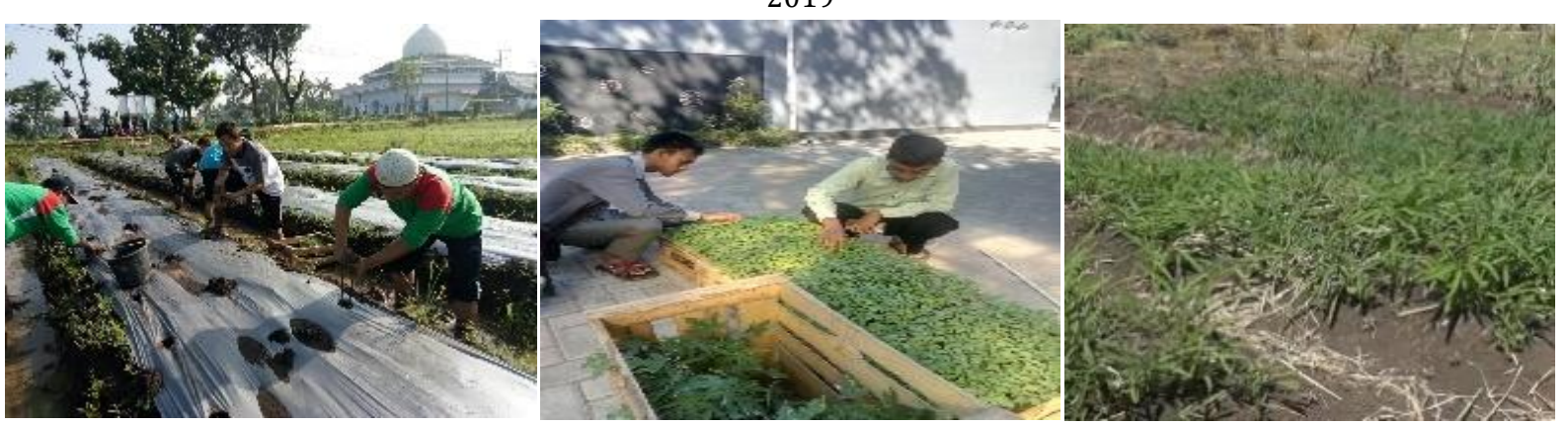

Fg. 6 Fresh Veta farm

Source: Authors (2018)

Al-Gitza unit is a start-up agribusiness unit for the purpose of mushroom production. The founders possess various formal education backgrounds in fields such as agro-technology, agro-industrial, and economics. The business unit is also located in Ponorogo, East Java. The mission of this business is to produce various kinds of mushrooms, and the major product from this farm is the oyster mushroom. In the future, the farm intends to produce fresh and snacked mushroom. The owners had just started in oyster mushroom cultivation and have no experience or entrepreneurial skill yet. The products would be offered to consumers directly without third parties such as retailers, wholesalers or other middlemen.

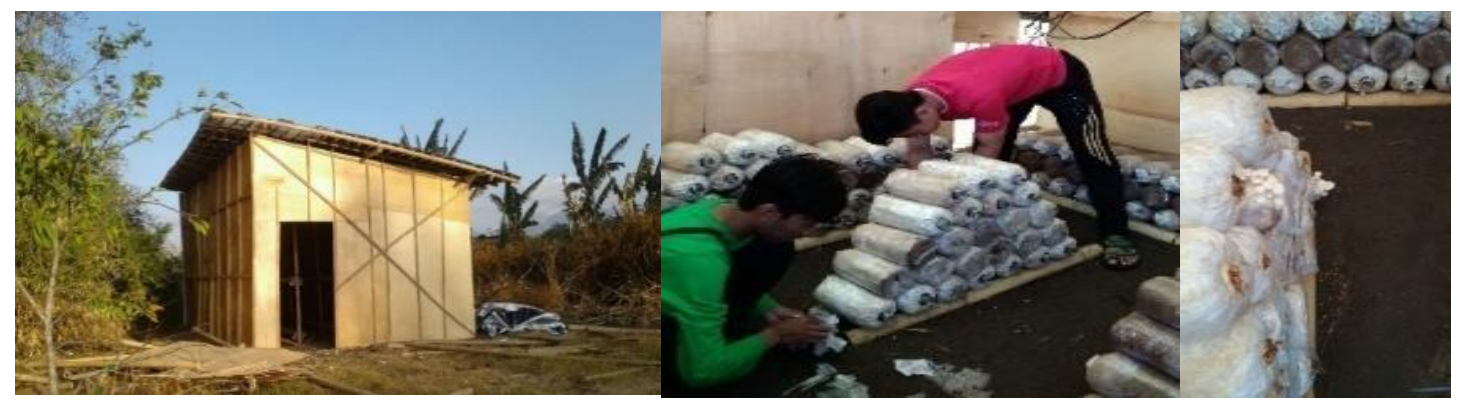

Fg. 7 Al-Gitza farms

Source: Authors (2018)

Joper unit is a start-up agribusiness unit for the purpose of poultry farming. The founders also have various backgrounds in formal education including in agro-technology and economics. The business unit is in Ponorogo, East Java. The major product from this farm is 
Alfu Laila, Lutfy Ditya Chayanti, Use Etica, Niken Trisnaningrum | ASEAN Journal of Community Engagement | Vol. 3, No. 1, 2019

chicken of the "Kampung" (Jowo Super) variety. The mission of this business is to produce this chicken variety with organic feed. The owners had just started raising this chicken variety as well as ducks with organic feed. They made organic feed by themselves. The owners who started out in poultry farming have no experience or entrepreneurial skill yet in areas such as production, financial management, and marketing. The products would be offered to consumers directly and through third parties such as retailers, wholesalers or other middlemen.

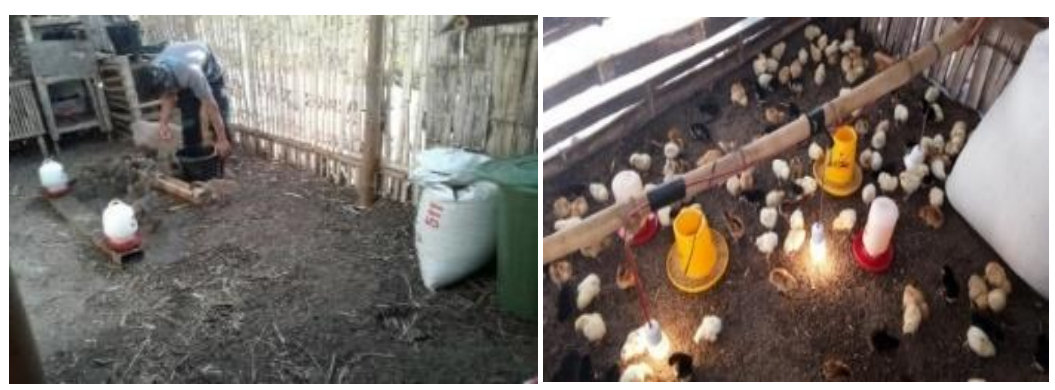

Fg. 8 Joper farm

Source: Authors (2018)

Nugget unit is a start-up agribusiness unit for the purpose of nugget production. The founders have various formal education backgrounds in agro-technology, agro-industrial, and economics. The business unit is in Ponorogo, East Java. The major product from this business is catfish nugget, which matches the mission of the business to produce catfish nugget. In the future, it intends to produce various fish nuggets. The owners who started the catfish nugget business have no experience or entrepreneurial skill in processing, financial management, and marketing. The first trial production had a terrible taste, texture, and packaging. Later, the products would be offered to consumers directly without third-party participants such as retailers, wholesalers or other middlemen. 


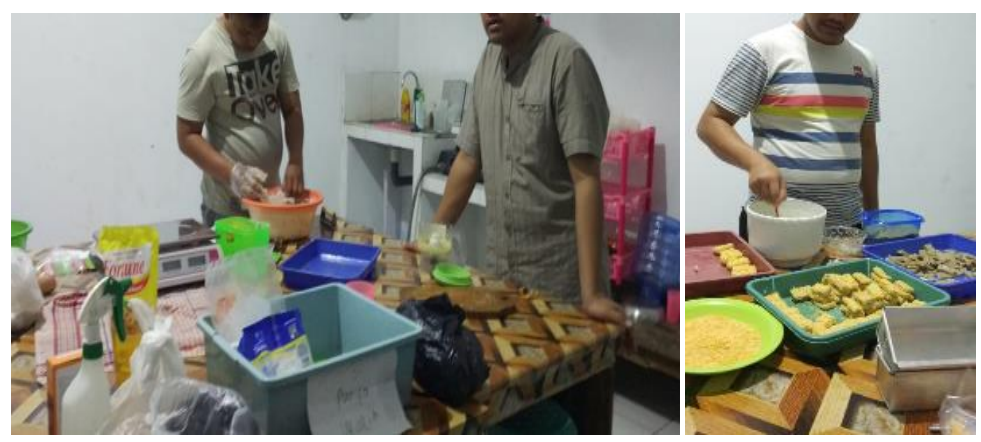

Fg. 9 Nugget production

Source: Authors (2018)

Chili is a start-up agribusiness unit for the purpose of horticulture production. The founders consist of individuals with various formal education backgrounds such as agrotechnology and agro-industrial. The business unit is in Ponorogo, East Java. The major product from this farm is red chili pepper. The mission of this business is to produce red chili pepper with low inputs. Throughout the early seasons, owners practiced monoculture of red chili pepper on half of the farm area. On the other area, they intercropped red chili pepper and watermelon. They would harvest chili at 4 months after planting while watermelon was harvested at 2 months after planting. In the monoculture area, the crop performance varied due to pest and disease attack, as well as unexpected drought in the rainy season. However, these caused increasing cost of production due to irrigation water and pesticide use. The monoculture area clearly had high risks of financial loss. Also, the price of red chili pepper is fluctuating. These products were offered to consumers directly and through third-party participants such as retailers, wholesalers or other middlemen. Mostly, the middlemen made the decision on price, making the final prices to be low at the farm in order to sell the product at higher profits. The owners who started horticultural production had less entrepreneurial skills to manage the cultivation costs along the way to make profitable. 

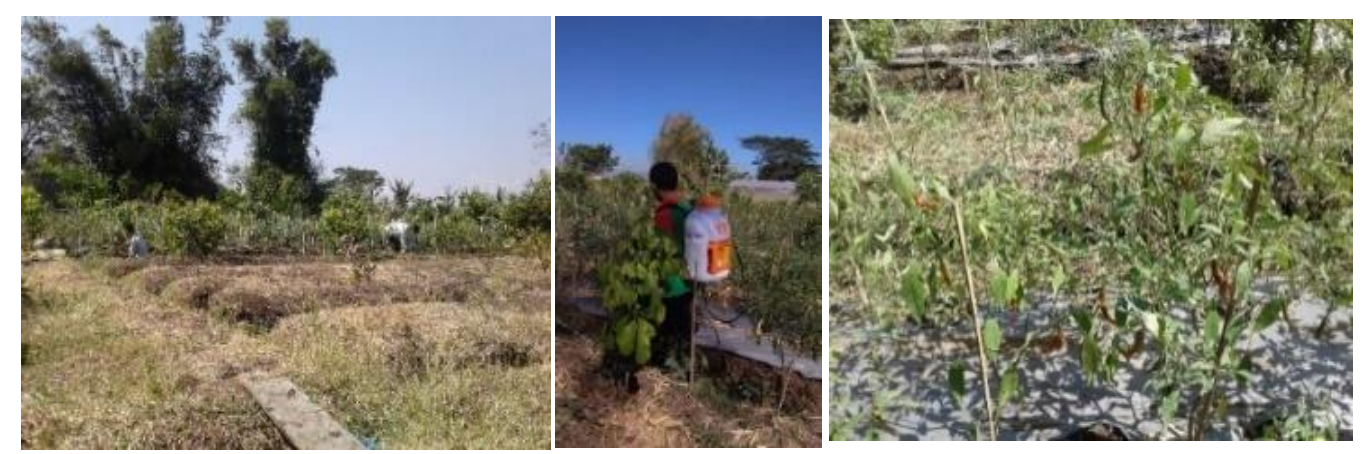

Fg. 10 Chili farms

Source: Authors (2018)

Fruida unit is a start-up agribusiness unit for the purpose of fruit juice production that started 2017. The founders have various formal education backgrounds such as agrotechnology and economics. The business unit is in Ponorogo, East Java. The major product from this business is fruit juice. The mission of the business is to produce fresh organic fruit juices and salads. In its early periods of production, they produced non-organic fresh fruit juices. Moreover, the packaging cup opened easily, so consumers found it uncomfortable. The products were offered to consumers directly without third parties such as retailers, wholesalers or other middlemen. The owners who were producing fruit juices have less experience and entrepreneurial skills in areas such as processing and marketing.

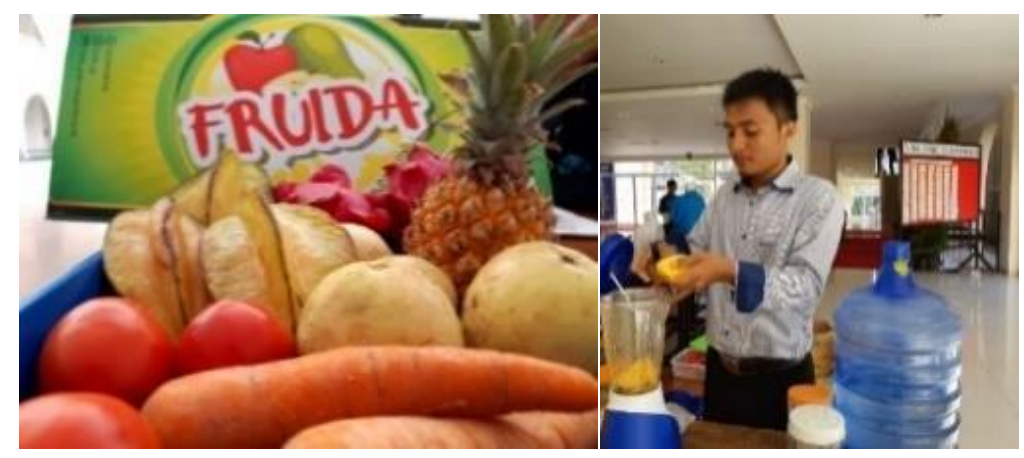

Fg. 11 Fruida processing

Source: Authors (2018)

Biofloc unit is a start-up agribusiness unit involved in fish farming since 2017. The founders have various formal education backgrounds in areas such as agro-technology and 
102

Alfu Laila, Lutfy Ditya Chayanti, Use Etica, Niken Trisnaningrum | ASEAN Journal of Community Engagement | Vol. 3, No. 1, 2019

economics. The business unit is in Ponorogo, East Java. The major product from this farm is catfish. The mission of the business is to produce catfish through a biofloc system. The biofloc system is a technology involving the use of treated wastes to feed fish at high stock densities. These products were offered to consumers directly and through third parties such as retailers, wholesalers or other middlemen. Throughout early production, the owners were involved in raising catfish at high stock density in tanks with a biofloc system. Unfortunately, percentage of mortality was high reaching $30 \%$ while the market demand was higher than their production capacity. Moreover, many consumers rejected their products because of the high variance in the size of catfish produced. The owners who started fish farming have less entrepreneurial skills to manage quantity and quality of product and thus make the products more acceptable and profitable.

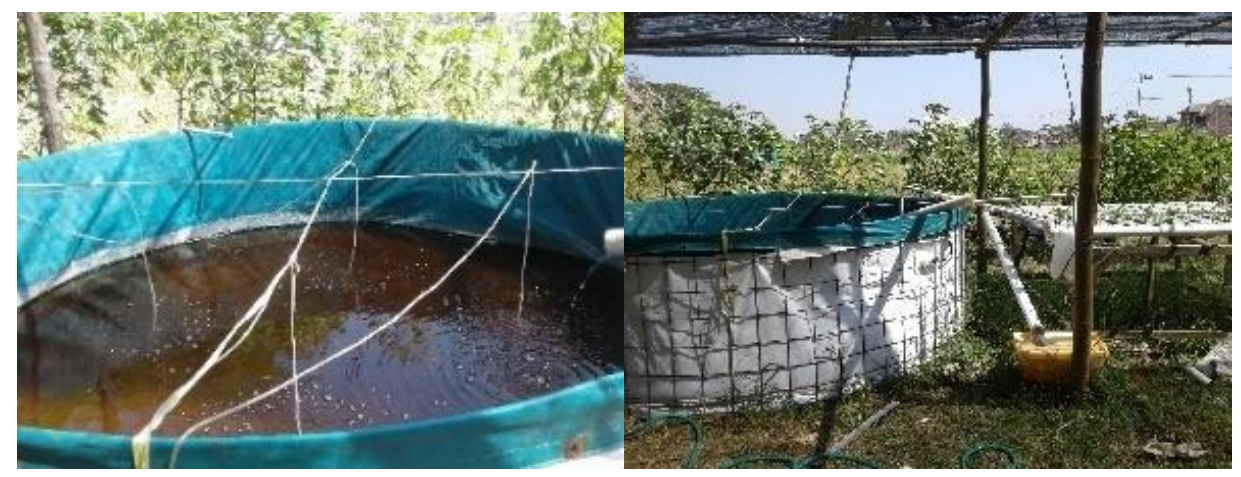

Fg. 12 Biofloc farm

Source: Authors (2018)

Glorins unit is a start-up agribusiness unit for the agro-industrial production that started in 2018. The founders possess varying qualifications in backgrounds such as agrotechnology, economics, and informatics. The business unit is in Ponorogo, East Java. The major product from this business is the palm sugar snack. The mission of this business is to be widely known in domestic and international markets. The owners who were producing Glorins had less experience and fewer entrepreneurial skills in areas such as processing and marketing. During early productions, the product was not proper for consumption due to a terrible taste and texture. It might be because the main source, palm sugar, was of low grade. The products were offered to consumers directly without third parties such as retailers, wholesalers or other middlemen. 


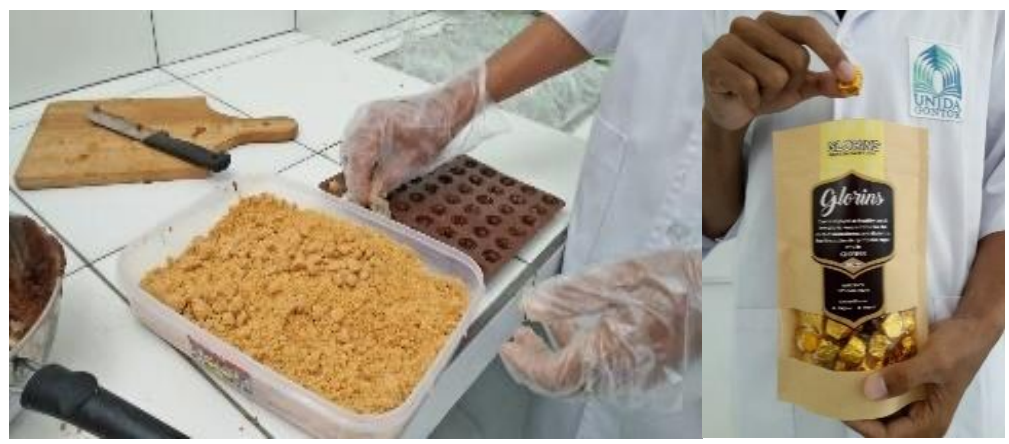

Fg. 13 Glorins product

Source: Authors (2018)

Authors noted some important points on owners' knowledge and entrepreneurship skills. In the production area, the owners had inadequate expertise to manage quantity and quality of products in order to make acceptable and profitable products. In fact, most of the business unit founders had an educational background in economics but had insufficient operating funds because they did not understand cash flow. All the business units reported poor management expertise in some of areas such as finance, marketing, and purchasing. This situation may cause failure in small businesses.

\subsection{Program, Target and Training Activity}

An analysis of the assessment made helped in the development of a program and a target for each business unit. Programs focused on three aspects, which were production, business feasibility, and marketing system (Table 2).

Table 2. Program, Target, and Activity

\begin{tabular}{lll}
\hline \multicolumn{1}{c}{ Program } & \multicolumn{1}{c}{ Target } & \multicolumn{1}{c}{ Activity } \\
\hline Improvement of & To increase production by & Creating of Standard Operating \\
Production & $10 \%$ & Procedures (SOPs) \\
& To decrease production & Mentoring enterprise activities \\
& cost by $10 \%$ &
\end{tabular}




\begin{tabular}{|c|c|c|}
\hline Program & Target & Activity \\
\hline \multirow{5}{*}{$\begin{array}{l}\text { Improvement of business } \\
\text { feasibility analysis }\end{array}$} & & Monitoring and evaluation \\
\hline & To develop strategic & Feasibility analysis workshop \\
\hline & business plans & \\
\hline & To plan for business & Business plan workshop \\
\hline & viability & \\
\hline \multirow{8}{*}{$\begin{array}{l}\text { Improvement of internet } \\
\text { marketing use }\end{array}$} & & Mentoring the development of \\
\hline & & business plans and feasibility \\
\hline & & analysis \\
\hline & To expand the product & Marketing website creation \\
\hline & awareness & workshop. \\
\hline & To develop marketing skill & Workshop on social media use \\
\hline & & for marketing \\
\hline & & Monitoring and evaluation \\
\hline
\end{tabular}

\section{a) Improvement of production}

On the production aspect, program activities aimed to improve capacity and reduce the cost of production. Targets were set to improve production capacity by up to $10 \%$, followed by decreasing the cost of production by up to 10\%. To achieve these objectives, programs were focused on three main activities namely, creation of operational SOP standards, mentoring enterprise activities, and monitoring and evaluation. In this step, participants were invited to conduct a study visit. The study visit aimed to provide participants with knowledge they can compare with their own experiences. In this section, participants acquired the expertise to walk around a business unit and assess the areas of strengths and weakness in its operations. This step included visits around varied business units spanning a wide range of sectors including aquaculture, poultry, and horticultural businesses. Visit included a presentation by the business owner, farm and field tours, and a question and 
Alfu Laila, Lutfy Ditya Chayanti, Use Etica, Niken Trisnaningrum | ASEAN Journal of Community Engagement | Vol. 3, No. 1, 2019

answer session (Figure 14). This was an opportunity to see how business management by different entrepreneurs compared with that of the participant businesses.

a

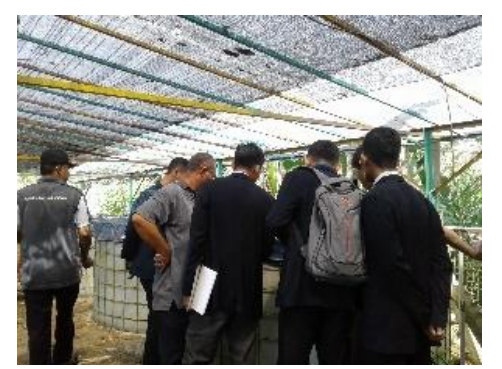

$\mathrm{b}$

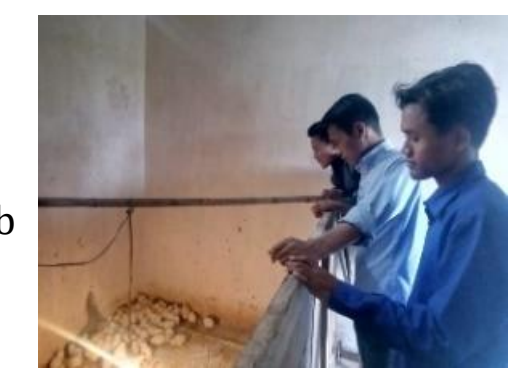

C
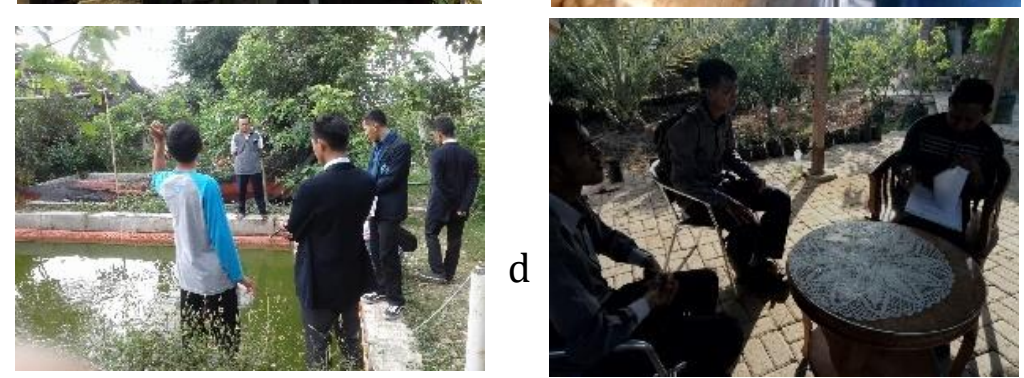

Fg. 14 Study visit to aquaculture (ab), poultry (c), and horticulture (d) business unit Source: Authors (2018)

Participants and their facilitators must spend some time discussing their knowledge production from visit study compared to the business in classroom daily activities (Figure 15). Every group had to create a Standard Operating Procedure (SOP). The SOP for each group would be reviewed by a specialist. Later, each group needed to revise the SOP after two weeks. After completing the SOP, every facilitator had to guide and mentor participants to implement activities based on the developed SOP. 

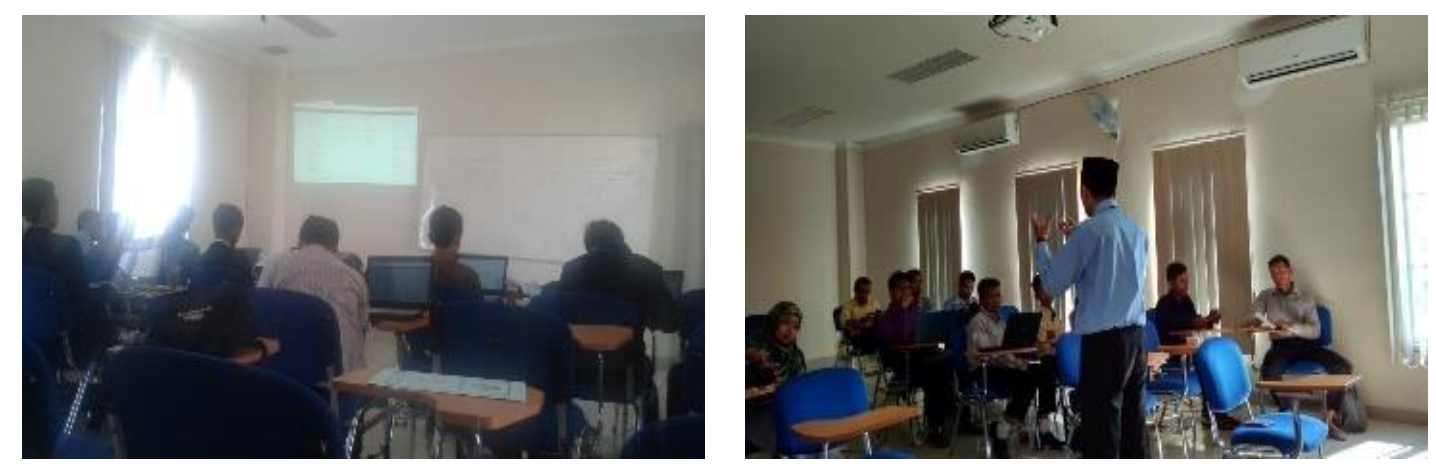

Fg. 15 SOP design activities

Source: Authors (2018)

\section{b) Improvement of business feasibility analysis}

To improve business feasibility analysis, three strategies were designed for developing a strategic business plan and achieving business viability. First, an expert was invited for a workshop on feasibility analysis to share his experiences with young enterprises (Figure 16). This section aims to foster willingness in considering new ideas to develop small businesses. Afterwards, participants were trained to create business plans and conduct feasibility analyses under supervision by a professional (Figure 17). All the business groups had to complete the plan in two weeks including review and revision by a supervisor. During this step, every facilitator had spent time guiding the participants until they completed the process.
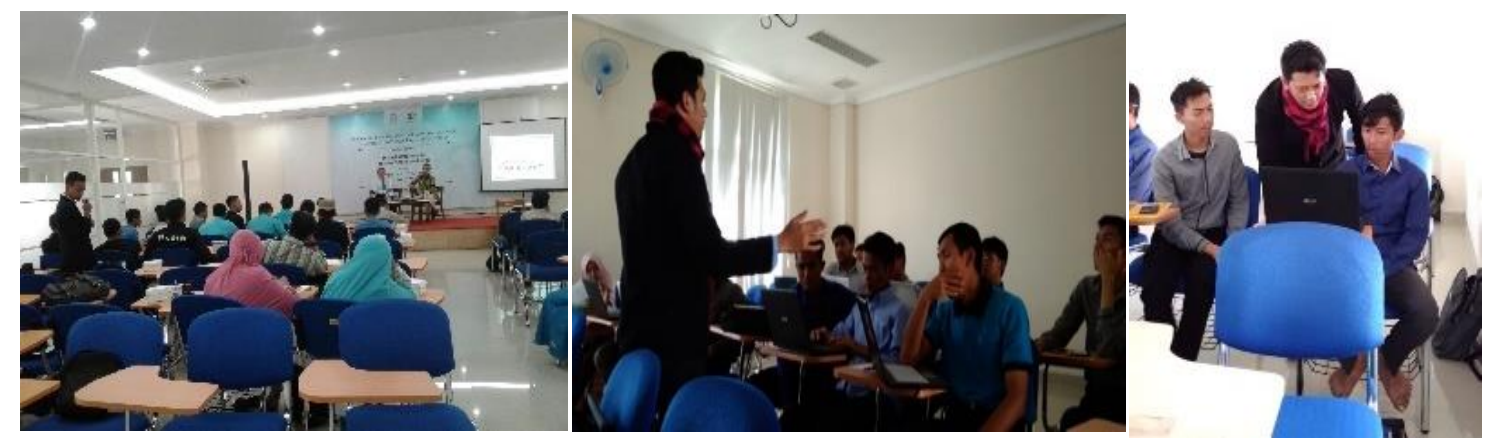

Fg. 16 Workshop on feasibility analysis and mentorship on creation of a business plan and feasibility analysis

Source: Authors (2018) 
Alfu Laila, Lutfy Ditya Chayanti, Use Etica, Niken Trisnaningrum | ASEAN Journal of Community Engagement | Vol. 3, No. 1, 2019

\section{c) Improvement of the marketing systems}

Improvement of the marketing systems aimed to expand product awareness and to develop marketing skills. A professional internet marketer was invited to train participants on creating websites and use of social media for marketing (Figure 17a). The next day, every business group created a website and a social media account on platforms, such as Instagram and Facebook. In this program, every facilitator assisted participants in creating social media accounts and websites for further promoting their products. In the future, participants intend to ensure their products are widely known not only in the domestic markets but also internationally. To achieve this objective, participants were invited to conduct a study visit to an organic horticulture entrepreneur who had expanded successfully, selling their products to Japan (Figure 17b). The visit included a presentation by the business owner, farm and field tour, and a question and answer session. The main theme of their discussion focused on export and import food product regulation. However, networking activities were more expected for participants in entrepreneurship education (Merle et al., 2014).

a

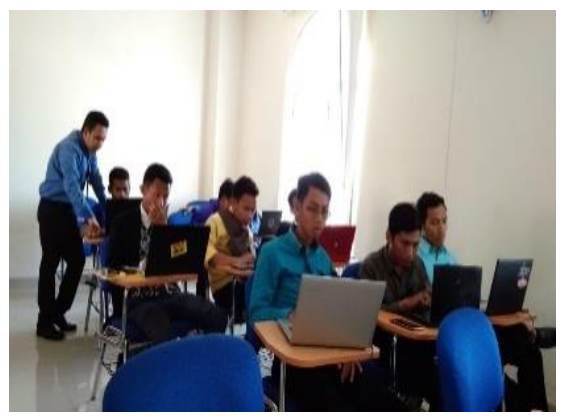

c

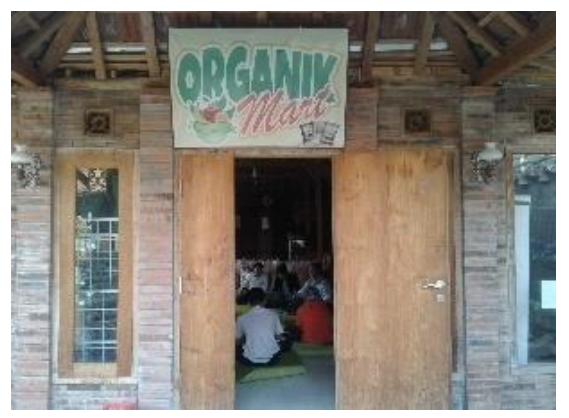

$\mathrm{b}$

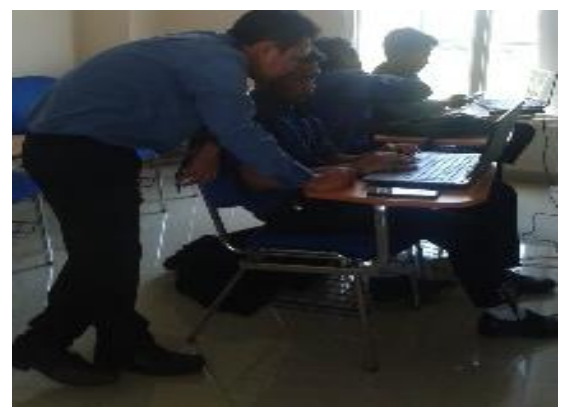

d

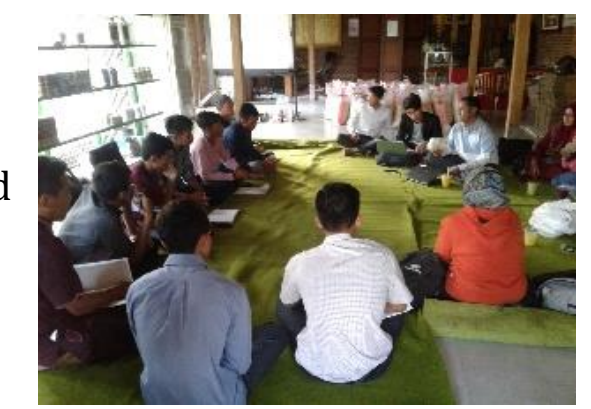

Fg. 17 Workshop on internet marketing (a), mentoring the use of social media for product promotion (b), and a study visit to an organic horticulture entrepreneur, Ponorogo Organic Centre (POC), East Java ( $c$ and d) 
Alfu Laila, Lutfy Ditya Chayanti, Use Etica, Niken Trisnaningrum | ASEAN Journal of Community Engagement | Vol. 3, No. 1,

\subsection{Result of Training Activities} 2019

After 6 months, this program solved the core problem of each business unit (Table 3).

Table 3. Results of Program Activities

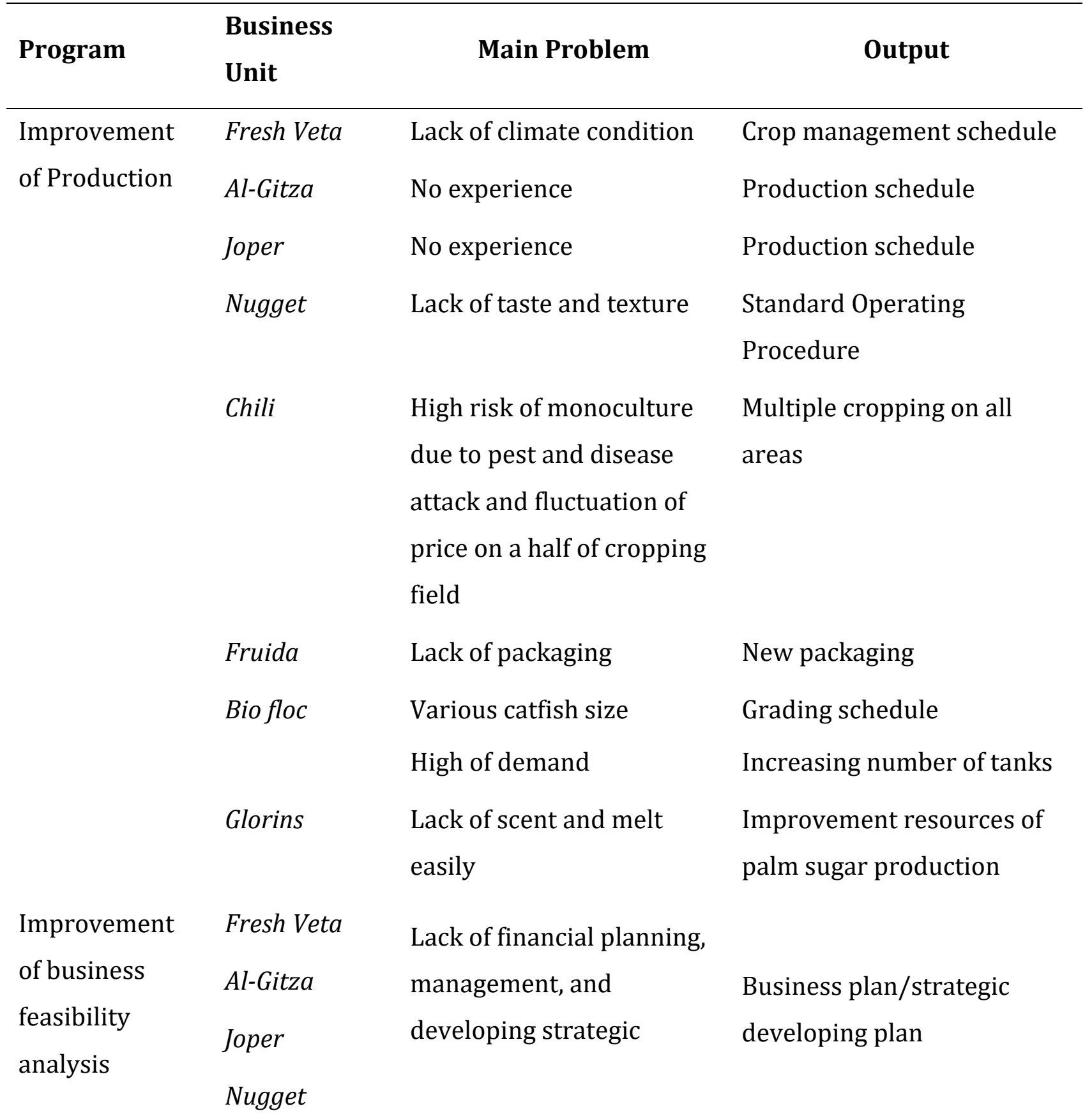




\section{Chili}

Fruida

Bio floc

Glorins

Improvement Fresh Veta

of internet Al-Gitza

marketing use

Joper

Nugget

Chili

Fruida

Bio floc

Glorins
Having Microsoft excel program template for recording financial data

Every business unit proficient in operating a website

Lack of marketing

development

Every business unit created accounts on social media

\section{a) Improvement of production}

Fresh Veta developed a crop management schedule and a crop rotation design. The crop management schedule consisted of irrigation, fertilization, mechanical and biological control to weeds, pests, and diseases. Crop rotation was conducted by rotating water spinach from one spot to another every week. The water spinach area was divided into four spots so owners could harvest water spinach every week. The water and nutrition needs were changed based on the different life stage of growth; for instance, the water spinach spots at a week after planting needed less water and low amounts of nutrition than mature plants. This method enhanced water use efficiency in order to provide different water needs on each spot every week. On the other hand, water spinach cultivation in some areas needed water, nutrition, and weed, pest and disease management simultaneously. However, the crop rotation design could help to avoid water deficiency during the dry period. This strategy did not only decrease yield losses in the dry period but also reduced the cost of production due to more efficient use of irrigation. Hence, cropping rotation was found to be a better 
Alfu Laila, Lutfy Ditya Chayanti, Use Etica, Niken Trisnaningrum | ASEAN Journal of Community Engagement | Vol. 3, No. 1, 2019

approach in an agricultural system (Teixeira et al., 2018). In this business, the major products from the farm are water spinach and tomato. Owners improved product value through packaging. These products were offered to consumers directly without third parties such as retailers, wholesalers or other middlemen.
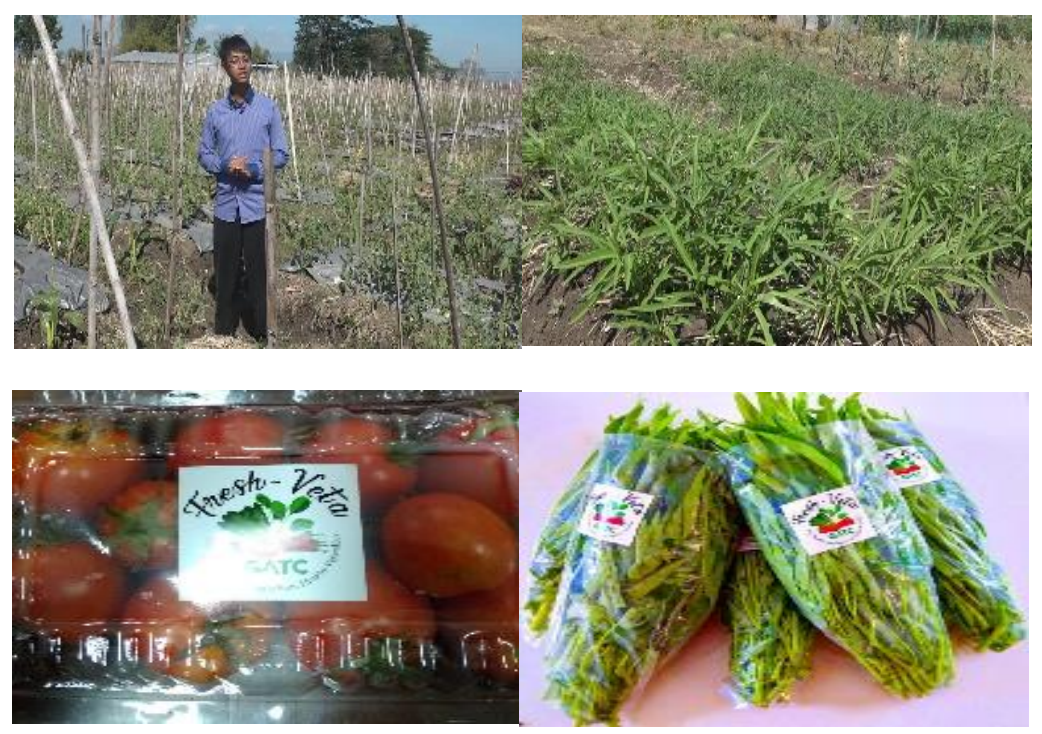

Fg. 18 Fresh Veta farm and their products after joining the entrepreneurship development program

Source: Authors (2018)

Al-Gitza developed a mushroom cropping management schedule for beginners. Cropping management consisted of media preparation, watering, and harvesting. The main aspect of crop management was the climatic condition through aspects such as temperature and relative humidity. Watering is major factor for mushroom cropping management to maintain low temperature and high relative humidity. In their first cultivation, they harvested oyster mushroom successfully three times a crop. Oyster mushroom is one of the easiest varieties of mushrooms to grow, delicious to eat, and is a healthy food. The products were offered to consumers directly. 

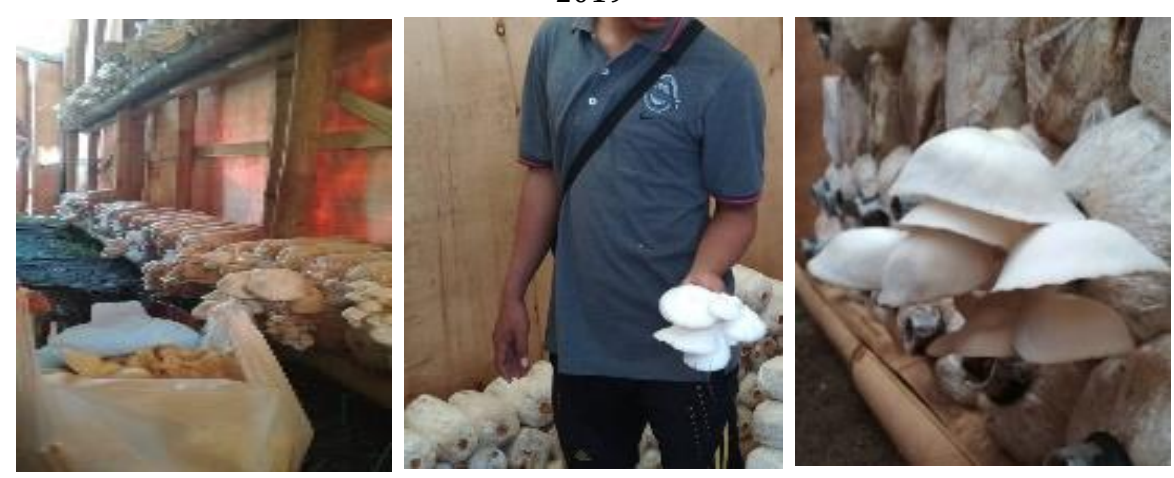

Fg. 19 Al Gitza farm and their product after joining the entrepreneurship development program

Source: Authors (2018)

After the SOP design workshop, Joper developed an SOP for organic feed formulation and a poultry management schedule. An organic feed means that whatever the chicken and ducks eat come from natural ingredients without any chemical content. The owners made organic feeds from organic wastes such as rice, vegetables, and fruits. Moreover, homemade poultry feed could decrease production cost because commercial poultry feed products are more expensive. One of the benefits of raising chicken organically was perceived as having high nutritional value and good flavor. Moreover, organic farming was known to be environmentally friendly (Sundrum, 2001). Poultry management included determining the breed, preparing brooders, focusing on sanitation, and nutrition schedule. In this first production, there were less than $10 \%$ chicken and duck poultry losses. It was so surprising although it was their first experience; they harvested and sold their products successfully at the best price. Their products offered to consumers directly and through third parties such as retailers, wholesalers or other middlemen. 

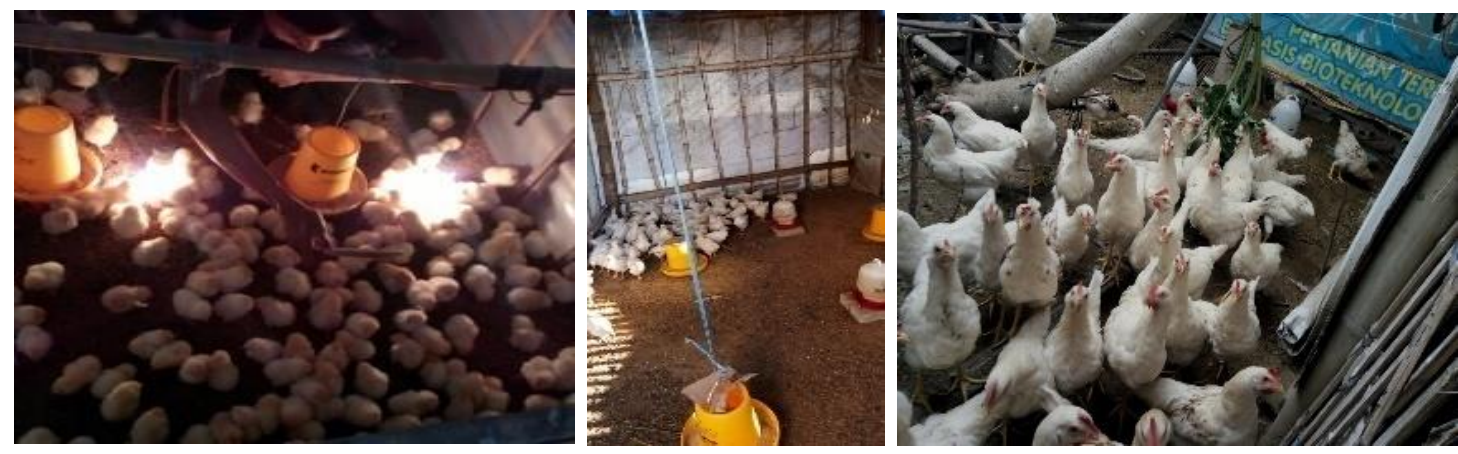

Fg. 20 Joper farm after joining the entrepreneurship development program

Source: Authors (2018)

Chili turned from the cultivation of a single crop to the cultivation of multiple crops at the same time and in the same area through the cultivation of chili and watermelon. However, single cropping or monoculture can increase the risk of pest and disease attacks. Diversity of crops can control pests and diseases without chemical inputs. Furthermore, long term polyculture has health benefits to the environment (Sanchez-Navarro et al. 2019) whereas continuous monoculture gradually depletes soil nutrients (Lu, He, and Liu, 2016). Crop management schedules consisted of irrigation, fertilization, mechanical, and biological control of weeds, pests, and diseases. Hence, multiple crops are necessary resources in terms of finance. Major products from this farm were red chili pepper. These products were offered to consumers directly and through third-party participants such as retailers, wholesalers or other middlemen. 

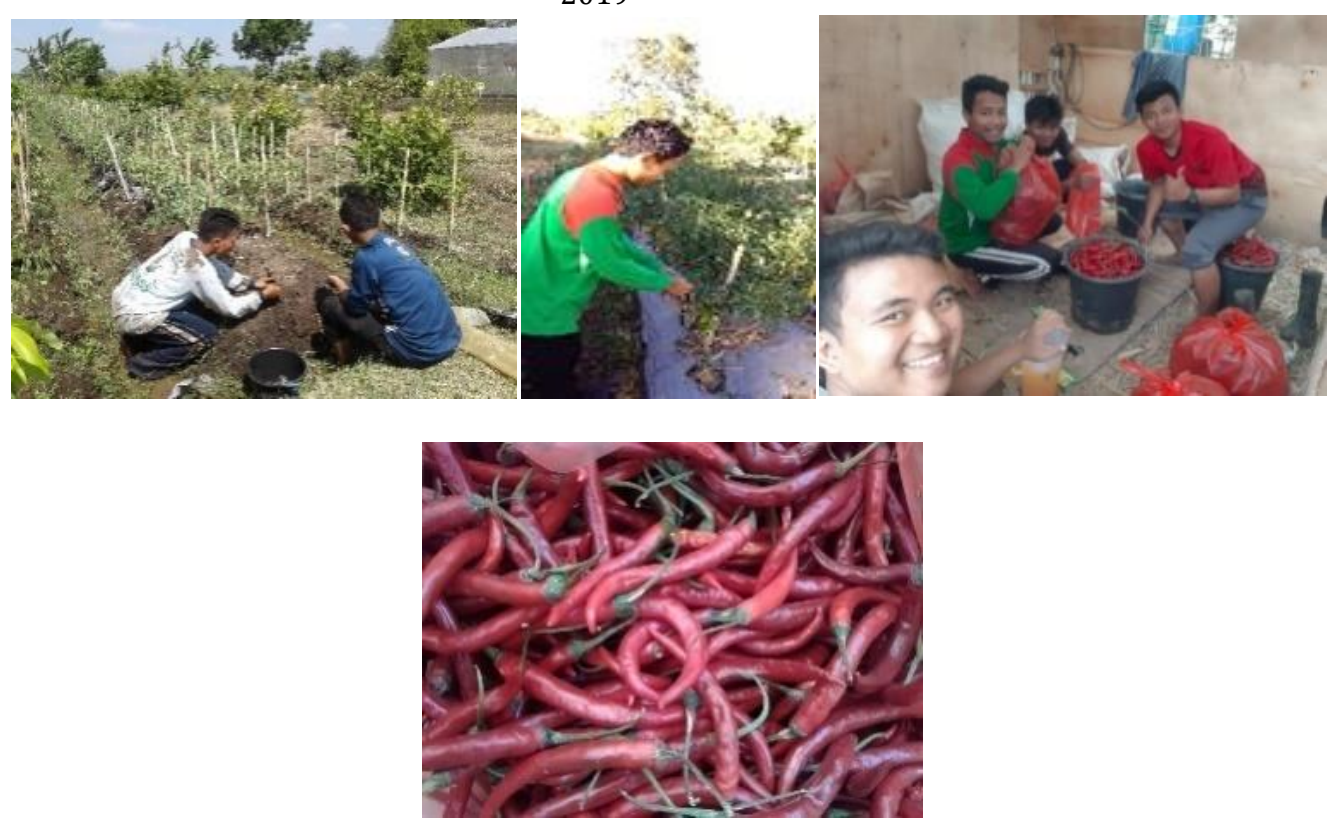

Fg. 21 Chili farm and their product after joining the entrepreneurship development program

Source: Authors (2018)

Packaging is a necessary consideration in quality food production. There is a wide variety of food packaging materials. Terrible packaging can change the color and taste of food. To increase quality of product, Fruida released new packages that can protect product quality during storage. The new packaging was better compared to old packaging material, which was a cup of juice whose seal opened easily and could change the taste because juice is extremely sensitive to oxidation. The new packaging could also make a good impression strategy. However, start-ups must design how to manage consumers trust perception for success (Elisa et al., 2019). After joining this program, the business owner enriched their products. Major products from this business were not only fresh fruit juice but also fruit salad. These products were offered to consumers directly. Also, owners promoted their products through social media and joined bazaar in order to be widely known. Furthermore, they offered delivery services, which were strategic to marketing development. 


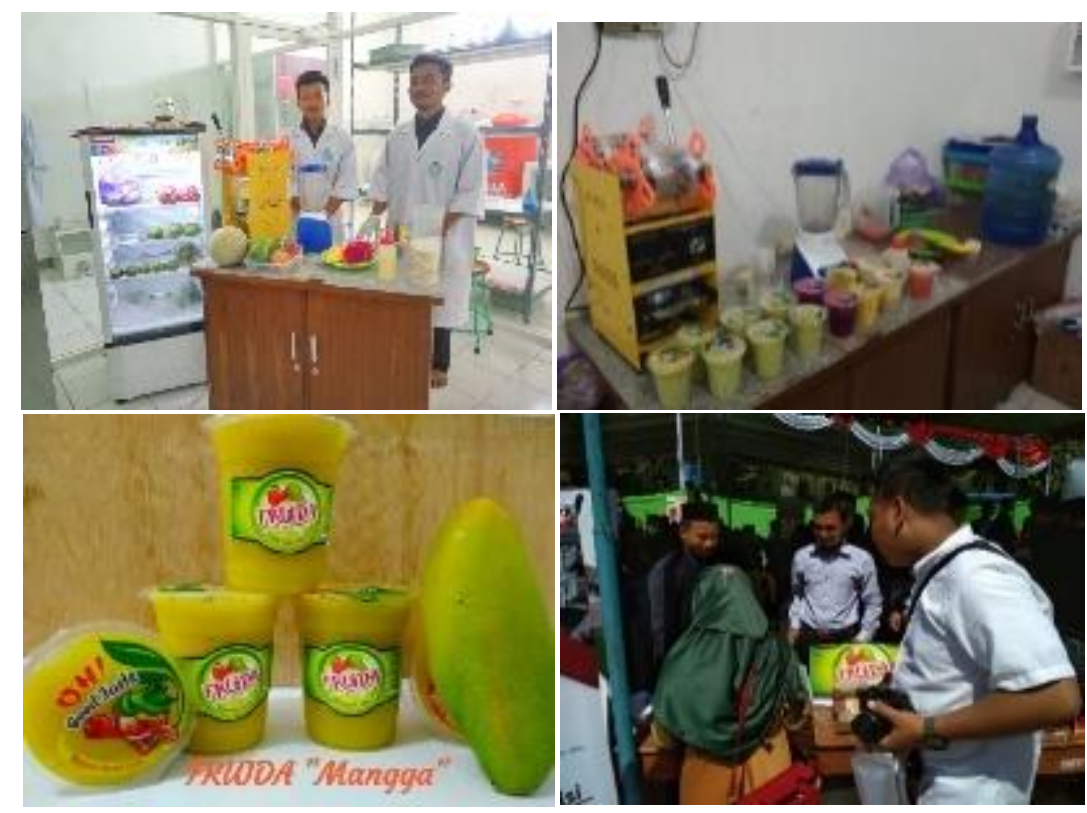

Fg. 22 Fruida activities, products, and in bazaar during joining entrepreneurship development program

Source: Authors (2018)

After this program, Biofloc group increased number of tanks to meet the high demand for catfish. Furthermore, they released a grading and sorting schedule so that the variance of catfish sizes decreased. Grading fish into groups of uniform sizes is a general management practice in aquaculture. Later, sorting involved separating a mixed size group into different tanks. Hence, grading and sorting could improve quality and quantity production, thereby stimulating increased sales and prices. During the practice of the grading schedule catfish losses could decrease from 30\% to 10\%. Decreasing yield losses and increasing product quality would increase profits. These products were offered to consumers directly.
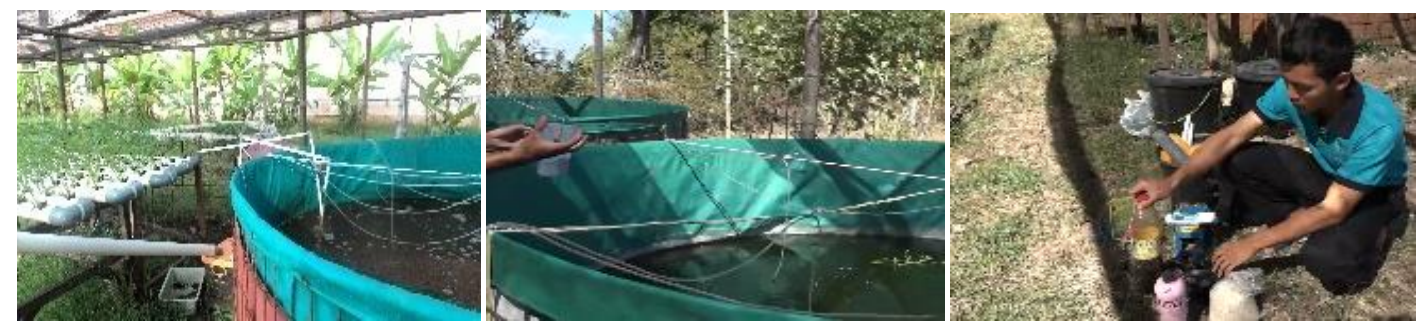

Fg. 23 Biofloc activities after joining the entrepreneurship development program Source: Authors (2018) 
Snacks food has potential nutrient-dense and health promoting diets. Glorins was designed for health promoting diets. Main source of Glorins is palm sugar, which has a low glycemic index (Srikaeo and Thongta, 2015) making it a healthier choice for diabetics. Poor quality of Glorins was caused by terrible quality of the source of palm sugar. However, good quality snack was made from high quality resources with the present technology under hygienic production. Owners improved the quality of their palm sugar source and conducted a nutrient content analysis. The products would be offered to consumers directly. The owners also promoted their products through social media and joined bazaar in order to be widely known.
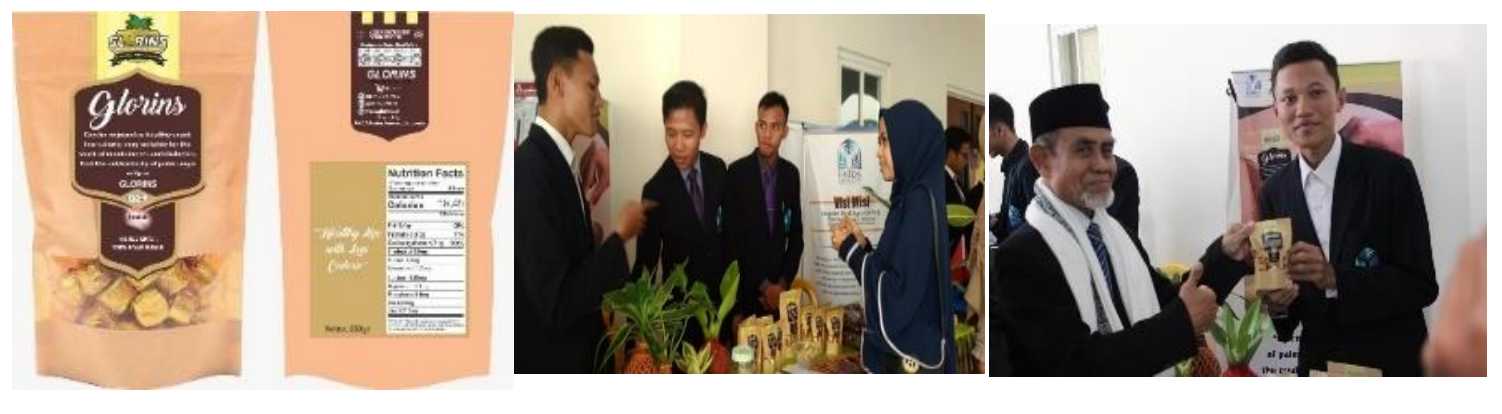

Fg. 24 Glorins products and in bazaar after joining the entrepreneurship development program

Source: Authors (2018)

Frozen food contains natural forms of preservatives. The quality is as good as that of fresh food. Freezing fish allows people to eat fish all the time so it is recommended as a way of maintaining nutritional diets. In this business, owners offer their products to foster healthy families. However, frozen fish is more durable than fresh fish because freezing can stop microbiological activity including that from pathogens that cause food poisoning. The lack of Nugget taste and texture in the first trial was caused by ingredients components and incorrect procedure. After several trial runs, they found the best recipe for fish nugget. There were two kinds of product offered to consumers namely, fish nuggets as frozen, and ready to eat. The products are offered to consumers directly without third-parties such as retailers, wholesalers or other middlemen. 


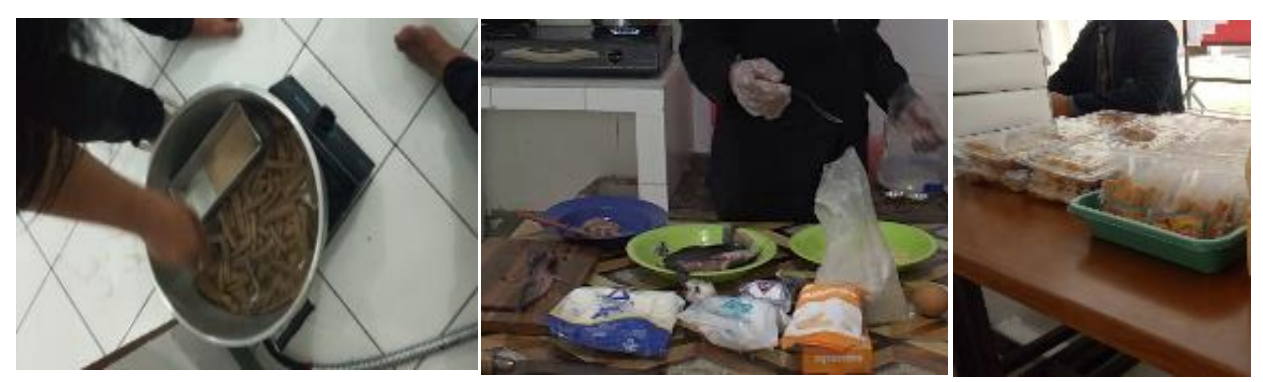

Fg. 25 Nugget products and in bazaar after joining entrepreneurship development program Source: Authors (2018)

\section{b) Improvement of business feasibility analysis}

Every business unit started recording financial data through a Microsoft excel program template so they could operate funds for further activities. Their current cash flow and feasibility analysis revealed that their revenue will be gained through the period from one to two years.

In the future, every business unit must develop a strategic plan. Owners examined the real demand, estimated the need, analyzed competitors, and validated promising opportunities. These were represented on their business plans. Their feasibility analysis revealed numerous barriers and opportunities for future business. For example, in the future, Fresh Veta, Chili, and Joper intend to produce organic products. It presents a big opportunity because consumer demand for organic products has been increased recently. On the other hand, they must be constrained by some barriers such as the transition period from conventional to organic farming, uncertainty in market accessibility, and organic certificate regulations. Al Gitza, Fish nugget, and Glorins have a big opportunity in the snacks food sector. However, snack food demands are increasing globally. Fruida has many obstacles in building systems and management, investment in infrastructure, and bringing innovation, since it become a franchise business.

\section{c) Improvement of internet marketing use}

All the business owners promote their products through social media in order to be widely known. It was strategic to develop a marketing network. For example, the first 
Alfu Laila, Lutfy Ditya Chayanti, Use Etica, Niken Trisnaningrum | ASEAN Journal of Community Engagement | Vol. 3, No. 1, 2019

costumer of Kampong chicken, who got information from Instagram, came from out of town. Glorins received an order from a consumer from abroad. Furthermore, Fruida could update promoting their new product through social media. Also, within social media, costumers could review products, providing feedback for product improvement. According to Lukes, Longo, and Zouhar (2019), in long term, innovative start-ups could speed up sales revenue.

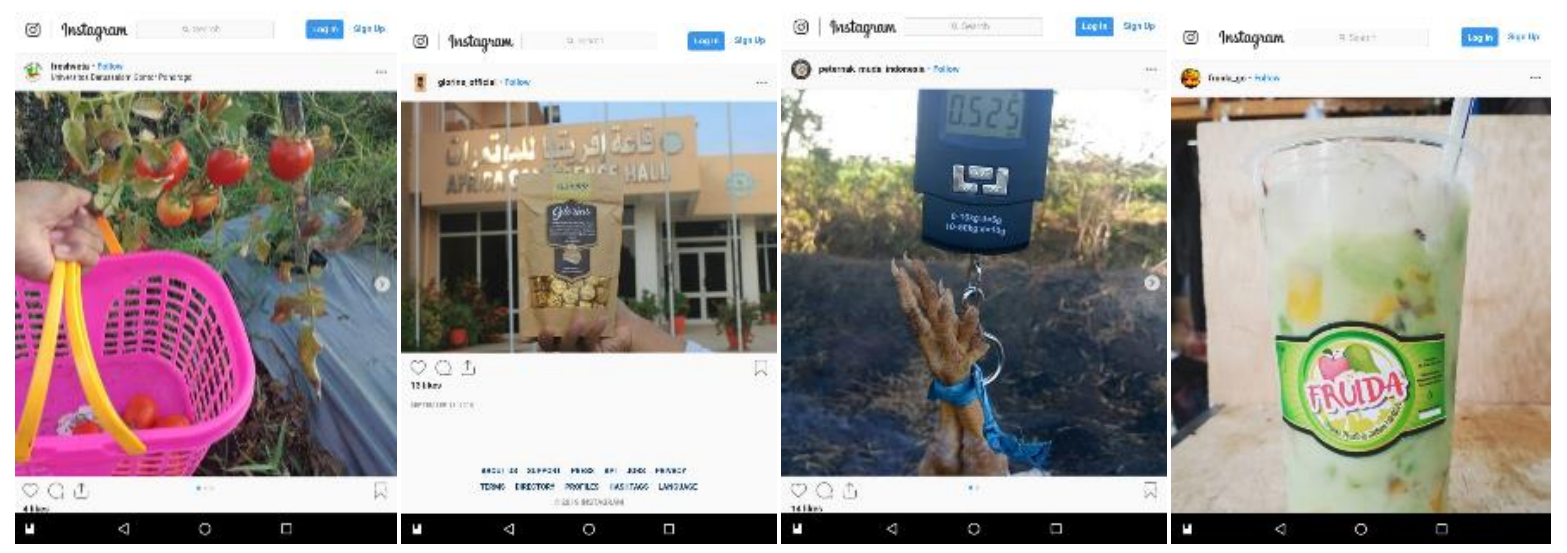

Fg. 26 Business unit on Instagram such as Fresh Veta, Glorins, Fruida, and Joper.

Source: IG @glorins_official. 2018,IG @fruida_go.2018I, @peternak_muda_indonesia, 2018

\subsection{General Evaluation}

An evaluation of this program showed that participants' entrepreneur skill enhanced gradually in production, financial management, and marketing. Good education in entrepreneurial skills could drive sustainable performance and growth of small-medium enterprises. Henceforth, small-medium enterprises contribute significantly to the development of an economic nation (Obi et al., 2018).

\section{Conclusion}

This program focused on the improvement of production, building financial systems, and expanding marketing network. After 6 months, acceleration of training and mentoring solved core problems on crop production through different methods. For instance, Fresh Veta, Al-Gitza, and Joper released management schedules; Chili turned from cultivation of single crop into multiple crops; Fruida released new packaging; Biofloc increased the number 
Alfu Laila, Lutfy Ditya Chayanti, Use Etica, Niken Trisnaningrum | ASEAN Journal of Community Engagement | Vol. 3, No. 1, 2019

of tanks and released a grading and sorting schedule; Nugget developed a formulation and production procedure; and Glorins improved the quality of its palm sugar source. To build a financial system, every group started recording financial data through a Microsoft excel program template and created a strategic plan based on present information and educated projections. Furthermore, every business unit is now proficient in operating a website and has accounts on social media to develop a marketing network. This program could enhance owner's entrepreneurial skills. In conclusion, good education in entrepreneurial skills in start-up businesses could drive sustainable performance and growth in small enterprises.

\section{Acknowledgements}

This program was funded by the Directorate for Higher Education, Ministry of Research, Technology and Education, Republic of Indonesia, through a grant to the Directorate for Research and Public Service.

\section{References}

Adjimah, P. H., and Akli L. P. 2014. "Effectiveness of Entrepreneurship Development Programs in Ghanaian." International Review of Management and Marketing 4(1): 7889.

Ardianti, R. 2009. “Entrepreneurship Education in Indonesia's Higher Education Institutions: A Solution for Problems Faced by The Next Generation." In London International Conference on Education (LICE-2009), UK, , 119-23.

Bauman, A., and C. Lucy. 2019. "Enhancing Entrepreneurial Education: Developing Competencies for Success." The International Journal of Management Education (In Press).

Bilali, H. E., and M. S. Allahyari. 2018. "Transition Towards Sustainability in Agriculture and Food Systems: Role of Information and Communication Technologies." Information Processing in Agriculture 5(4): 456-64.

Bureau, Central Statistical. 2018. Central Statistical Bureau.

Cui, J., J. Sun, and R. Bell. 2019. “The Impact of Entrepreneurship Education on the 
Alfu Laila, Lutfy Ditya Chayanti, Use Etica, Niken Trisnaningrum | ASEAN Journal of Community Engagement | Vol. 3, No. 1, 2019

Entrepreneurial Mindset of College Students in China: The Mediating Role of Inspiration and the Role of Educational Attributes." The International Journal of Management Education (In Press).

Elisa, K-B., M. C. Schuhmacher, S. Kuster, and V. Kuharev. 2019. “Making a First Impression as a Startup: Strategies to Overcome Low Initial Trust Perception in Digital Innovation Adoption." International Journal of Research in Marketing (In Press).

Ghina, Astri. 2014. "Effectiveness of Entrepreneurship Education in Higher Institutions.” In Procedia-Social and Behavioral Science, The 5th Indonesia Conference on Innovation, Entrepreneurship, and Small Business (IICIES 2013), 332-45.

Hadi, C., I. Suardi, and A. Cahaya. 2015. "Entrepreneurship and Education: Creating Business Awareness for Students in East Java Indonesia." Procedia-Social and Behavioral Sciences 177: 459-63.

Khayri, Shaghayegh, Jfar Yaghoubi, and Masoud Yazdanpanah. 2011. "Investigating Barriers to Enhance Entrepreneurship in Agricultural Higher Education from the Prespective of Graduate Students." Procedia Social and Behavioral Science 15: 2818-22.

Kurniati, Edy Dwi. 2015. "Entrepreneurial Empowerment of Agriculture and Industrial Sector in Rural Areas of Semarang Regency Indonesia." Asian Economic and Financial Review 5(4): 723-33.

Lu, G., G. He, and W. Liu. 2016. "Long-Term Cropping Effects on Agricultural Sustainability in Alar Oasis of Xinjiang, China." Sustainability 8(16): 1-16.

Lukes, M., M. C. Longo, and J. Zouhar. 2019. “Do Business Incubators Really Enhance Entrepreneurial Growth? Evidence From a Large Sample of Innovative Italian StartUps." Technovation 82-83: 25-34.

Masur, Yogita V., Veena S. Jadhav, and K. Sarojani. 2014. "Entrepreneurship Development Programmes Offered for Women by KVK and RUDSETI." Advance Research Journal of Social Science 5(2): 188-92.

Merle, K., M. Kallaste, U. Venesaar, and A. Kiis. 2014. "Entrepreneurship Education at University Level and Students' Entrepreneurial Intentions." Contemporary Issues in Business, Management and Education 110: 255-65. 
Alfu Laila, Lutfy Ditya Chayanti, Use Etica, Niken Trisnaningrum | ASEAN Journal of Community Engagement | Vol. 3, No. 1, 2019

Ministry of Research, Technology and Higher Education. 2013. Higher Educational Statistical Year Book 2013.

\section{__—. 2018. Higher Educational Statistical Year Book 2018.}

Nemcek, Bystrik, Iveta Kremenova, and Juraj Fabus. 2015. "An Analysis of Unemployment Due to Number of University Graduates in the Slovak Republic." Procedia-Social and Behavioral Science 174: 2395-2400.

Noya, S., and E. A. Setiyati. 2015. "Evaluating Entrepreneurship Education Model in Indonesian University (Case Study: Universitas Ma Chung)." Business \& Entrepreneurship Journal 4(2): 21-30.

O., Arodudu, K Helming, H Wiggering, and A Voinov. 2017. "Bioenergy from Low-Intensity Agricultural Systems: An Energy Efficiency Analysis.” Energies 10(29): 1-18.

Obi, J. et al. 2018. "Contribution of Small and Medium Enterprise to Economic Development: Evidence from a Transiting Economy." Data in brief 18: 835-39.

Onuekwusi, G. C., E. Odoemelam, E. Lovina, and U. Charles. 2014. “Entrepreneurship Development Programme: Intervention Mechanism in Agriculture for Youth Unemployment in Abia State, Nigeria." International Journal of Information and Communication Technology Research 4(5): 179-86.

Priyanto, S. H. 2012. "Entrepreneurial and Vocational Learning in Entrepreneurship Education: Indonesian Non Formal Education Perspective." Basic Research Journal of Business Management and Accounts 1(2): 30-36.

Rahmat, Putra Ahmad Hasibuan, Dede Ruslan, and Fitrawaty. 2017. "The Effect of Education on Unemployment Rate in Indonesia." In Proceedings of The 2nd Annual International Seminar on Transformative Education and Educational Leadership (AISTEEL),.

Ridha, R. N., and B. P. Wahyu. 2017. "Entrepreneurship Intention in Agricultural Sector of Young Generation in Indonesia." Asia Pacific Journal of Innovation and Entrepreneurship 11(1): 76-89.

Sanchez-Navarro, V., R. Zornoza, A. Faz, and J. Fernandez. 2019. “Comparing Legumes for Use in Multiple Cropping to Enhance Soil Organic Carbon, Soil Fertility, Aggregates Stability and Vegetables Yields Under Semi-Arid Conditions." Scientica Horticulturae 246: 835- 
Alfu Laila, Lutfy Ditya Chayanti, Use Etica, Niken Trisnaningrum | ASEAN Journal of Community Engagement | Vol. 3, No. 1, 2019

41.

Seuneke, P., T. Lans, and J. S. Wiskerke. 2013. “Moving Beyond Entrepreneurial Skills: Key Factors Driving Entrepreneurial Learning in Multifunctional Agriculture." Journal of Rural Studies 32: 208-19.

Srikaeo, K., and R. Thongta. 2015. "Effects of Sugarcane, Palm Sugar, Coconut Sugar and Sorbitol on Starch Digestibility and Physiochemical Properties of Wheat Based Foods." International Food Research Journal 22(3): 923-29.

Sundrum, A. 2001. “Organic Livestock Farming: A Critical Review." Livestock Production Science 67(3): 207-15.

Teixeira, E. I. et al. 2018. "Adapting Crop Rotations to Climate Changes in Regional Impact Modelling Assessments." Science of Total Environment 616-617(789-795).

Utami, C. W. 2017. “Attitude, Subjective Norms, Perceived Behavior, Entrepreneurship Education and Self-Efficacy Toward Entrepreneurial Intention University Student in Indonesia." European Research Studies Journal 20(2A): 475-95.

Zaky, M. A. et al. 2018. Mapping and Database Start-up Indonesia 2018. 